\title{
CUSTOMER SATISFACTION STUDY OF GEPREK CHAMPION CHICKEN BRANCH MAKMUR MEDAN
}

\author{
Sarmauli Hanny Siagian ${ }^{* 1}{ }^{\circledR}$, M. Umar Maya Putra ${ }^{2}$, Davin Kwok ${ }^{1}$ \\ ${ }^{* 1}$ Management Department, STIE Mikroskil Medan, Indonesia \\ 2 Management Department, Universitas Al Azhar Medan, Indonesia
}

DOI: https://doi.org/10.29121/ijetmr.v7.i10.2020.795

Article Citation: Sarmauli Hanny Siagian, M. Umar Maya Putra, and Davin Kwok. (2020). CUSTOMER SATISFACTION STUDY OF GEPREK CHAMPION CHICKEN BRANCH MAKMUR MEDAN. International Journal of Engineering Technologies and Management Research, 7(10), 73-79.

https://doi.org/10.29121/ijetmr.v7 .i10.2020.795

Published Date: 30 October 2020

Keywords:

Quality

Service

Atmosphere

Satisfaction

\begin{abstract}
This study aims to analyze the effect of product quality, service quality and store atmosphere on customer satisfaction on Geprek Champion Chicken in Makmur Medan Branch. The sample used in this study were 96 respondents who were consumers of the Geprek Champion Chicken Restaurant in Medan, using the sampling technique, namely icidental sampling using the lemeshow formula. The data collection technique uses a questionnaire that has been tested for its validity and reliability. The results of research partially $t$ test results indicate that product quality, service quality and store atmosphere have a significant effect on customer satisfaction. Simultaneously, the variable product quality, service quality and store atmosphere have an effect on customer satisfaction.
\end{abstract}

\section{INTRODUCTION}

In this era of globalization, the culinary business is growing rapidly because every day people need food and there are many innovations or new ideas from the younger generation that are poured into new menus in the culinary business. The current fact, the growth of the culinary business in Medan can be seen from the number of restaurants that are increasing every month, coupled with different concepts. So that business competition in the city of Medan is becoming increasingly complicated.

This makes all restaurants in Medan demanded to be able to compete in developing products and provide the best for consumers. This is because understanding and fulfilling consumer desires is one way to achieve customer satisfaction. Many factors can affect customer satisfaction. Because, consumers nowadays are very careful in assessing products, both from the quality of the products served to how the services provided from the restaurant. Besides that, the atmosphere of a restaurant or store atmosphere is also an important factor in the culinary business. One of them is a restaurant that is developing in Medan, namely Geprek Champion Chicken, Branch of Makmur Medan. This restaurant is located on Jl. Makmur No. 44 - 30, Medan City.

Product quality is a set of features and characteristics of a product or service to satisfy stated or implied needs. In determining the products to be offered, companies must adjust to consumer tastes so that consumers feel satisfied [1]. Factors that affect the quality of food products include taste, freshness, appearance, maturity and variety of food.

(C) 2020 The Author(s). This is an open access article distributed under the terms of the Creative Commons Attribution License, which permits unrestricted use, distribution, and reproduction in any medium, provided the original author and source are credited. 
The taste of food is one of the factors that determine the taste of food. The purpose of processing and cooking food is to produce food with high taste so that it is satisfying for those who eat it.

Service quality is the level of excellence expected and control over these excellence to meet customer desires [2]. Like what consumers do when they are at a restaurant, where consumers assess the time of serving and the way of serving and the cleanliness of restaurant equipment. Due to the fact that in today's era, many restaurants pay less attention to serving time so that many consumers cancel orders because of the length of the dishes that come.

Store atmosphere is an important component of a shop or cafe and can provide the dominant sensory effect created by a shop or café design [3]. When consumers have their needs, wants or tastes met, then at that time customer satisfaction has been fulfilled. Consumer satisfaction is the feeling of pleasure or disappointment of someone who comes from a comparison between his impression of the performance (results) of a product with his expectations [4].

Based on the results of the pre-survey conducted to several its consumers ask to improve the quality of the dishes and the food. The appearance of the product must be more attractive and more innovative. The design if its atmosphere can be adjusted to youngsteers who like to get the newest service and attractive in technoly. Those are some of the consumer hopes that must be improved from the restaurant.

The Research Objectives are determining the effect of Product Quality, Quality, Store Atmosphere on customer satisfaction at Geprek Champian Chicken Branch Makmur Medan partially and simulteneously

\section{MATERIALS AND METHODS}

\subsection{CUSTOMER SATISFACTION}

Consumer satisfaction is a post-purchase evaluation, in which perceptions of the performance of the selected alternative products meet or exceed expectations before purchase [5]. Consumer satisfaction is the level of feeling happy or disappointed someone that arises because of comparing the perceived performance of the product (or result) received as expected, so the consumer will feel satisfied [6]. Consumer satisfaction indicators are as follows:

1) Their Willingness to visit again

2) Confirm expectations

3) Willingness to recommend [7]

\subsection{PRODUCT QUALITY}

Product quality is a direct description of a product such as performance, reliability, easy to use aesthetics and so on [8]. Product quality is the ability of a product to carry out its function, including durability, reliability, accuracy, ease of operation and repair, as well as other valuable attributes [9].

\subsection{QUALITY OF SERVICE}

Service quality in simple terms, namely, a measure of how well the level of service provided is in accordance with consumer expectations [10]. This means that the quality of service is determined by the ability of a particular individual or company to meet needs in accordance with what is expected or desired based on the needs of consumers or buyers. Service quality is the level of excellence expected and control over these excellence to meet customer desires [2].

\subsection{STORE ATMOSPHERE}

Store atmosphere is an important component of a shop or café and can provide the dominant sensory effect created from a shop or café design [1]. Store atmosphere is a physical characteristic that is very important in creating a comfortable atmosphere for consumers who are in a shop or café and can indirectly influence consumer image and purchasing behavior [11]. 


\subsection{CONCEPTUAL THEORY}

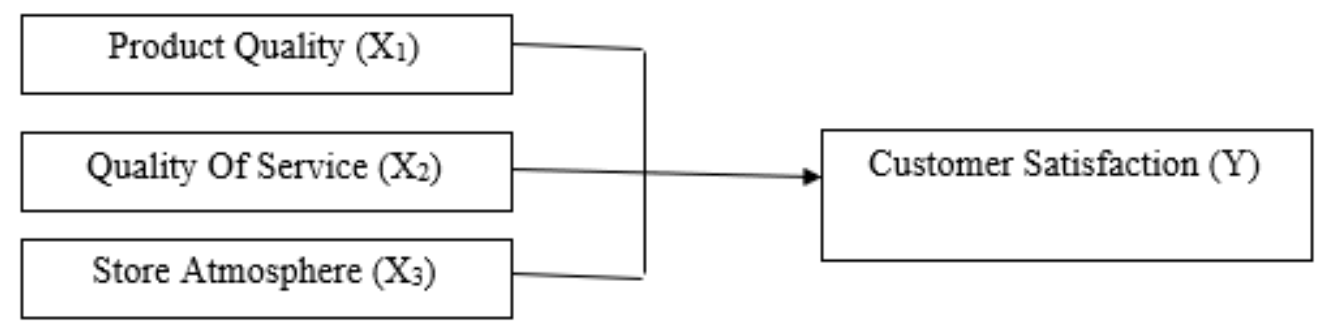

\subsection{HYPOTHESIS DEVELOPMENT}

H1: There is an effect of product quality on consumer satisfaction of Geprek Chicken Champion in Makmur Medan Branch

H2: There is an effect of service quality on customer satisfaction in Geprek Champion in the Makmur Medan Branch.

H3: There is an effect of store atmosphere on consumer satisfaction in the Geprek Champion Chicken in the Makmur Medan Branch.

H4: There is an influence between product quality, service quality, and store atmosphere on customer satisfaction on the Geprek Champion Chicken in the Makmur Medan Branch.

\section{RESULTS AND DISCUSSIONS}

\subsection{RESEARCH METHODS}

This type of research is a descriptive study with a quantitative approach. Descriptive research is intended to collect all information about the symptoms that are present or according to the circumstances at the time the research was conducted [12]. Whereas what is meant by a quantitative approach is an approach used to test theories, and build facts, show the combination of variables, statistical descriptions, estimate and predict the results. Research designs that use a quantitative approach must be structured, standardized, formal and designed as well as possible before [12].

In this study, the population was all consumers of the Geprek Juara Chicken Restaurant, Makmur Medan Branch who made purchases during the study period starting in December 2019 to May 2020. The sample size in this study was determined by the lemeshow formula because the population in this study could not be known. how many the exact number. The sampling technique in this study uses a nonprobability sampling technique, namely a sampling technique that does not provide an opportunity or opportunity to be selected as a sample [13]. The sampling technique used in this study is Incidental Sampling. Incidental sampling is a sampling technique based on chance, in which anyone who happens to meet the researcher can be used as a sample [13]. Then the results obtained from the minimum number of samples needed in this study were 96 respondents.

The data collection method in this research is using a questionnaire (questionnaire), observation, and interviews. The data analysis method in this research is descriptive statistics, data quality testing, namely validity and reliability tests, classical assumption tests, namely: multicollinearity test, normality test and heteroscedasticity test, partial significance test ( $\mathrm{t}$ test), simultaneous significant test (f test), and the coefficient of determination test.

\subsection{OPERATIONAL DEFINITION OF VARIABLES}

The definitions of the variables studied are as follows:

- Product quality (X1) is one of the most desirable factors for consumers to fulfill their wants and expectations.

- Service Quality (X2) is good service from the restaurant to consumers who are at the restaurant. 
- Store atmosphere (X3) is the atmosphere in the restaurant that must provide comfort and beauty for consumers while in the restaurant.

- Consumer Satisfaction (Y), namely consumers who are satisfied when they are inside the restaurant because all their expectations for the restaurant are fulfilled so that they want to return to the restaurant and are willing to recommend it to their family or other people.

\subsection{THE MULTIPLE REGRESSION RESULT}

Table 1: The Multiple Regression Result

\begin{tabular}{|c|c|c|c|c|c|c|}
\hline \multicolumn{7}{|c|}{ Coefficients $^{a}$} \\
\hline & \multirow[t]{2}{*}{ Model } & \multicolumn{2}{|c|}{ Unstandardized Coefficients } & \multirow{2}{*}{$\begin{array}{c}\text { Standardized Coefficients } \\
\text { Beta }\end{array}$} & \multirow[t]{2}{*}{$\mathrm{t}$} & \multirow[t]{2}{*}{ Sig. } \\
\hline & & B & Std. Error & & & \\
\hline \multirow[t]{4}{*}{1} & (Constant) &,- 201 & 211 & &,- 953 & ,343 \\
\hline & Product Quality &, 556 & 101 & , 476 & 5,511 &, 000 \\
\hline & Service Quality & 182 & 071 & 176 & 2,552 & 012 \\
\hline & Store Atmosphere & 304 & 089 & 317 & 3,426 & 001 \\
\hline
\end{tabular}

Based on Table 4.4 above, the multiple linear regression equation can be formulated as follows:

Customer Satisfaction $=-0.201+0.556$ Product Quality +0.182 Service Quality +0.304 Store Atmosphere

The interpretation of the Multiple Linear Regression equation above is as follows:

1) The constant value of -0.201 indicates a negative value, which means that if the variable product quality, service quality and store atmosphere is considered zero, then customer satisfaction is -0.201 units.

2) The value of the Multiple Linear Regression Coefficient for the product quality variable shows a positive value of 0.556 , which means that if the product quality variable increases by one unit, then customer satisfaction will increase by 0.556 if other variables are considered constant.

3) The value of the multiple linear regression coefficient for the service quality variable shows a positive value of 0.182 which means that if the service quality variable increases by one unit, the consumer's purchasing decision will increase by 0.182 if the other variables are considered constant.

4) The value of the multiple linear regression coefficient for the store atmosphere variable shows a positive value of 0.304 which means that if the store atmosphere variable increases by one - unit, then customer satisfaction will increase by 0.304 if other variables are considered constant. The main results should be presented clearly and briefly, insisting on their significance and degree of novelty.

Based on the partial test in table 4.8, it can be seen that the test results for each independent variable are as follows:

1) The test results for the product quality variable show the tcount value of $5.511<$ ttable of 1.98609 with a significance value of $0.000<0.05$, then the hypothesis Ha is accepted and Ho is rejected, which means that product quality has a significant effect on consumer consumer satisfaction.

2) The test results for the service quality variable show the tcount of $2.552>t$ table of 1.98609 with a significance value of $0.012<0.05$, then the hypothesis Ha is accepted and Ho is rejected, which means that service quality has a significant effect on customer satisfaction.

3) The test results for the store atmosphere variable show that the $t$-count value is $3,426<t$ table of 1.98609 with a significance value of $0.001<0.05$, then the hypothesis Ha is accepted and Ho is rejected, which means that store atmosphere has a significant and significant effect on customer satisfaction. 
Sarmauli Hanny Siagian, M. Umar Maya Putra, and Davin Kwok

Table 2: Simultaneous Hypothesis Testing Results (Test F)

\begin{tabular}{|c|c|c|c|c|c|c|}
\hline \multicolumn{7}{|c|}{ ANOVA $^{\mathrm{a}}$} \\
\hline \multirow{2}{*}{1} & Model & Sum of Squares & df & Mean Square & F & Sig. \\
\cline { 2 - 7 } & Regression & 57,919 & 3 & 19,306 & 142,549 &, $000^{\mathrm{b}}$ \\
\cline { 2 - 7 } & Residual & 12,460 & 92 &, 135 & & \\
\cline { 2 - 7 } & Total & 70,379 & 95 & & & \\
\hline \multicolumn{2}{|l|}{ a. Dependent Variable: Customer Satisfaction } \\
\hline
\end{tabular}

Based on the results of the simultaneous test above, with a value of Fcount $42.549>$ Ftable 2.70 and a significance of $0.000<0.05$, so the hypothesis Ho is rejected and Ha is accepted. So it can be concluded that the three variables, namely product quality, service quality and store atmosphere simultaneously influence customer satisfaction.

Table 3: Results of the Coefficient of Determination $\left(\mathrm{R}^{2}\right)$

\begin{tabular}{|c|c|c|c|c|}
\hline \multicolumn{4}{|c|}{ Model Summaryb $^{\mathrm{b}}$} \\
\hline Model & $\mathrm{R}$ & R Square & Adjusted R Square & Std. Error of the Estimate \\
\hline 1 &, $907 \mathrm{a}$ &, 823 &, 817 &, 368 \\
\hline \multicolumn{4}{|l}{ a. Predictors: (Constant), Store Atmosphere, Service Quality, Product Quality } \\
\hline \multicolumn{4}{|l}{ b. Dependent Variable: Customer Satisfaction } \\
\hline
\end{tabular}

The results of the coefficient of determination can be seen from the Adjusted R Square of 0.817 which shows how much the proportion and total variation in consumer purchasing decisions can explain product quality, service quality and store atmosphere by $81.7 \%$ and the remaining $18.3 \%$ is influenced by other variables not examined in this study.

\section{DISCUSSION}

1) The influence of product quality variables on customer satisfaction

The product is the core of a marketing activity because the product is the output or result of one of the company's activities or activities that can be offered to the target market to meet the needs and desires of consumers [8]. From the results of this study, product quality has an effect on customer satisfaction. This indicates that the better the quality of the product, the more satisfied consumers will be. By paying attention to product quality, it will be a separate consideration for consumers to make their choices. But even so, the Geprek Champion Chicken Restaurant in the Prosperous Medan Branch must still pay attention to and maintain the cleanliness of food and drinks, not only the appearance of food and drinks is considered but coupled with the waiting time for food orders until the shirt arrives, the shirt is not too long so it creates additional value. for the quality of existing products in the Geprek Champion Chicken Restaurant Branch of the Prosperous Medan Branch.

2) The Effect of Service Quality on Customer Satisfaction

Service quality is simple, namely, a measure of how well the level of service provided is in accordance with consumer expectations [10]. This means that the quality of service is determined by the ability of a particular individual or company to meet needs in accordance with what is expected or desired based on the needs of consumers or buyers. Service quality is the level of excellence expected and control over these excellence to meet customer desires [2].

In this study, service quality has a significant effect on customer satisfaction, meaning that service quality is an important factor affecting customer satisfaction. Based on this research, it shows that in the service quality variable, the average consumer answers neutral to the service quality incator, namely hospitality, responsiveness and speed and attention. This means that consumers do not care about the quality of service provided by the Geprek Chicken Champion in the Prosperous Medan Branch. Even so, the Geprek Ayam Geprek Champion Restaurant in Medan's Prosperous Branch still has to improve the quality of their service in order to maintain their customer satisfaction. 
3) The Effect of Store Atmosphere on Customer Satisfaction

Store atmosphere is a physical characteristic that is very important in creating a comfortable atmosphere for consumers who are in a store or café and can indirectly influence consumer image and purchasing behavior [11]. In this study, store atmosphere has an effect on customer satisfaction. This means that the atmosphere of the restaurant affects consumer satisfaction, the more the atmosphere of the restaurant is made comfortable, attractive and shows the characteristics of the restaurant, the more satisfied it will be. Paying attention to the atmosphere of a restaurant can be an important consideration for businesses in the culinary field, by making the restaurant atmosphere comfortable, attractive and showing characteristics to attract consumers and making them visit again because they feel satisfied so that the restaurant business is able to compete with other restaurants because it has advantages. .

4) The Effect of Product Quality, Service Quality and Store Atmosphere on Customer Satisfaction

The effect of these three variables on consumer satisfaction because the better the quality of restaurant products and the better the quality of service and the more comfortable the atmosphere of the restaurant is, and has an attractive design, it makes consumers feel satisfied and makes consumers return to visit the Geprek chicken restaurant, the champion branch of the prosperous field of Medan.

\section{CONCLUSIONS AND RECOMMENDATIONS}

From the results of this study, the following conclusions can be drawn:

1) Partially, the variable of product quality has a significant effect on consumer satisfaction in Geprek Juara Chicken, Makmur Medan Branch because the quality of the products must be improved in taste, durability and product appearance togain more customers.

2) The service quality variable has a significant effect on customer satisfaction at Geprek Chicken, Makmur Medan Branch partially because the quality of service provided by the employees is not in accordance with customer satisfaction

3) The Store Atmosphere variable has a significant effect on consumer satisfaction at Ayam Geprek Juara, Makmur Branch Medan, because the atmosphere at Ayam Geprek Juara, Makmur Medan Branch partially and must make the place comportable with the menu display book available.

4) Product quality, service quality and store atmosphere have a significant effect on consumer satisfaction because it provides customer satisfaction. It should provide good product quality and satisfactory service quality and store comfortable atmosphere so that consumers feel like home that customer satisfaction can be created and they will visit again

\section{SOURCES OF FUNDING}

None.

\section{CONFLICT OF INTEREST}

None.

\section{ACKNOWLEDGMENT}

None.

\section{REFERENCES}

[1] Iis Maulidah, Joko Widodo dan Mukhamad Zulianto, Pengaruh Kualitas Produk dan Kualitas Pelayanan terhadap Kepuasan Konsumen di Rumah Makan Ayam Goreng Nelongso Jember, Jurnal Pendidikan Ekonomi, Vol.13, No.1, E-ISSN 2548-7175 ISSN 1907-9990, 2019. 
[2] Budi D. Soebakir, Bode Lumanauw dan Ferdy Roring, Pengaruh Brand, Harga Dan Kualitas Pelayanan Terhadap Keputusan Pelanggan Membeli Di Kedai Kopi Gudang Imaji, Jurnal Ekonomi, Manajemen, Bisnis dan Akuntansi, Vol. 6, No. 4, ISSN 2303-1174, 2018.

[3] Maria Kristiana, Pengaruh Store Atmosphere Dan Kualitas Layanan terhadap Kepuasan Konsumen Cafe Heerlijk Gelato Perpustakaan Bank Indonesia Surabaya, Jurnal Pendidikan Tata Niaga, Vol.1, No.1, ISSN: 23376708, 2017.

[4] Handayani Natalia Siregar, Arlin Ferlina Mochamad Trenggana, Pengaruh Kualitas Pelayanan dan Kualitas Produk terhadap Kepuasan Konsumen pada Kfc Cabang Buah Batu Bandung, Jurnal Administrasi Bisnis, Vol.3, No.2, ISSN: 2355-9357, 2016.

[5] F. Tjiptono, Strategi Pemasaran, Edisi ke-4, Yogyakarta: CV. Andi, 2015.

[6] Kotler, Philip and K. L. Keller, Marketing Management, 15th Edition New Jersey, Pearson Pretice Hall, Inc, 2016.

[7] F. Tjiptono, Service Quality \& Satisfattion, Edisi ke-4, Yogyakarta: CV. Andi Offset, 2016.

[8] A. Buchori, Manajemen Pemasaran dan Pemasaran Jasa, Bandung: CV. Alpabeta, Edisi Revisi, 2016.

[9] Kotler, Philip dan Amstrong, Principles of Marketing, Global Edition, Person Education, Harlow, 2016.

[10] F. Tjiptono dan G. Chandra, Service, Quality and Statisfaction, (ed 3). Yogyakarta: Andi, 2011.

[11] B. Berman, dan J.R. Evans, Retail Management: A Strategic Approach, Eleventh Edition: Upper Saddle River, New: Jersey: Prentice Hall, 2010.

[12] S. Arikunto, Prosedur Penelitian: Suatu Pendekatan Praktik, (13 ed), Jakarta: Rineka Cipta, 2006.

[13] Sugiyono, Metode Penelitian Kuantitatif, Kualitatif, dan R\&D, Cetakan Ke-25, Bandung: Alfabeta, 2017. 